\title{
Rapid antibody test for prenatal diagnosis of fragile X syndrome on amniotic fluid cells: a new appraisal
}

Rob Willemsen, Frans Los, Serieta Mohkamsing, Ans van den Ouweland, Wout Deelen, Hans Galjaard, Ben Oostra

\begin{abstract}
Fragile $X$ syndrome is caused by mutations in the FMR1 gene and is one of the most frequent forms of inherited mental retardation in males. Postnatal and prenatal diagnosis of fragile $X$ syndrome is feasible by direct DNA analysis. A new approach to prenatal diagnosis of fragile $X$ syndrome in amniotic fluid cells is described, using a rapid and simple antibody test on uncultured amniotic fluid cells. The test requires $1 \mathrm{ml}$ of amniotic fluid and the results of this antibody test are available on the same day as the amniocentesis.

(F Med Genet 1997;34:250-251)
\end{abstract}

Keywords: prenatal diagnosis; fragile $\mathrm{X}$ syndrome; amniotic fluid; FMRP.

Recently we described a simple and rapid antibody test on blood smears to identify male and female fragile X patients. ${ }^{12}$ Briefly, cells from fragile $X$ patients contain large CGG expansions (over 200 CGG repeats, full mutation) in the FMR1 gene, resulting in hypermethylation of the CGGs and the $\mathrm{CpG}$ island ${ }^{3}$ (for review see Hoogeveen and Oostra ${ }^{5}$ ). As a consequence, no transcription of the FMR1 gene occurs, resulting in absence of the protein product of the FMR1 gene, FMRP. ${ }^{6}$ The FMR1 gene is expressed in almost every tissue and cell type. Lack of expression of FMRP is responsible for the mental retardation seen in fragile $X$ patients, one of the clinical characteristics of fragile $\mathrm{X}$ syndrome. Thus, the absence or presence of FMRP in cells can be used as a diagnostic tool. ${ }^{12}$

Prenatal diagnosis of the fragile $\mathrm{X}$ syndrome can be performed either on chorionic villi or amniotic fluid cells. In both tissues a direct DNA analysis (Southern blotting) of the mutation responsible for the fragile $\mathrm{X}$ syndrome is carried out. ${ }^{78} \mathrm{~A}$ major disadvantage of prenatal DNA diagnosis of fragile $X$ syndrome on cultured amniotic fluid cells is the time span between amniocentesis and results of the DNA analysis.

\section{Subjects and methods}

We have tested the method on a fragile X family. The pregnant mother, who is a carrier of a premutation and had prenatal diagnosis in two earlier pregnancies, requested prenatal diagnosis. Amniocentesis was performed at 17 weeks of gestation. We used uncultured amniotic fluid cells from non-fragile $\mathrm{X}$ fetuses as controls Amniotic fluid was either used directly or stored at $4^{\circ} \mathrm{C}$ overnight. The amount of amniotic fluid to be used at this gestational age is 1 $\mathrm{ml}$. The sample was centrifuged at $1000 \mathrm{rpm}$ for 10 minutes. Amniotic fluid cells were washed once in $0.1 \mathrm{~mol} / 1$ phosphate buffered saline (PBS, $\mathrm{pH}$ 7.3) followed by a second centrifugation step. The pellet was resuspended in $100 \mu \mathrm{l} 0.1 \mathrm{~mol} / 1 \mathrm{PBS}$ and subsequently this suspension was used for making cytospins using a cytofuge (Nordic, Tilburg, The Netherlands). Slides were fixed in 3\% paraformaldehyde for 10 minutes, followed by a permeabilisation step in $100 \%$ methanol for 20 minutes. For immunocytochemistry, a three step alkaline phosphatase technique was performed as previously described ${ }^{12}$ (see also Internet http:/ /www.eur.nl/FGG/CH1/fragx). In parallel, DNA analysis was carried out on cultured amniotic fluid cells as described before. ${ }^{9}$

\section{Results and discussion}

The expression of FMRP in fresh amniotic cells is illustrated in fig 1 . In cells from a control fetus, a clear reaction product (red) was observed in the cytoplasm, reflecting the presence of FMRP (fig 1A). In contrast, cells from the male fetus, at risk for fragile $\mathrm{X}$ syndrome, showed no reaction product, illustrating the absence of FMRP (fig 1B). Only occasionally was a positive labelled cell encountered. We have indicated in the top right corner of each figure the percentage of positive labelled cells Apparently, this affected fetus shows a mosaic pattern with respect to FMRP expression, a phenomenon also observed in the antibody test on blood smears. ${ }^{7}$ Using the antibody test on cultured amniotic cells from control fetuses and this affected fetus resulted in an overal high background, making interpretation of the results impossible. DNA analysis of cultured amniotic fluid cells from the affected male fetus showed a full mutation in the FMR1 gene that was fully methylated, in line with the absence of FMRP (data not shown). The results of the DNA analysis took over two weeks after amniocentesis, whereas the immunocytochemical data were available the same day. So far only one affected fetus has been studied in this way.

To validate this new test more data are necessary. However, in our Institute most of the prenatal diagnoses for fragile $\mathrm{X}$ syndrome are 


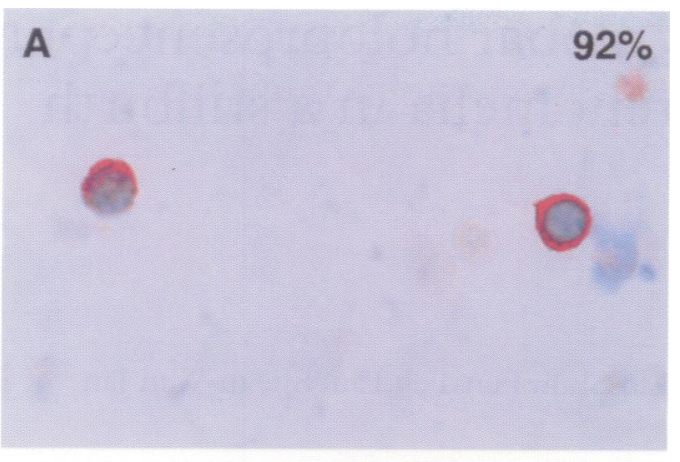

B

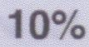

Figure 1 FMRP expression in fresh amniotic fluid cells from a contol fetus $(A)$ and an affected fetus $(B)$, both at 17 weeks of gestational age. In the top right corner we have indicated the percentage of positive labelled cells in the cytospin preparation.

performed on chorionic villi. This may be different in other countries. In some institutes in the USA, $40 \%$ of the prenatal diagnostic tests for fragile $\mathrm{X}$ syndrome are carried out on amniotic fluid cells (W $T$ Brown, personal communication). For validation, a substantial number of samples from affected fetuses are needed. In order to realise this we would like to introduce this antibody test on uncultured amniotic fluid cells in routine prenatal diagnosis. The use of $1 \mathrm{ml}$ of amniotic fluid is sufficient for immunocytochemical analysis, making this method extremely economical with respect to sample quantity and thus very suitable in combination with routine DNA diagnostic methods.

In conclusion, the first results of the protein test on uncultured amniotic fluid cells are promising as an alternative test for prenatal diagnosis of fragile $\mathrm{X}$ syndrome. In particular, the short time span between amniocentesis and the result of the antibody test is a great advantage for the parents. Recently, we described an antibody test on chorionic villi for prenatal diagnosis of fragile $\mathrm{X}$ syndrome. ${ }^{10}$ For this method we used tissue sections from chorionic villi at 12.5 weeks of gestational age making this method somewhat complicated with respect to technical parameters compared with the method on uncultured amniotic fluid cells. In a first step to routine application of both methods, we would like to suggest performing both methods in the first instance in laboratories that already have experience with the antibody test on blood smears.

1 Willemsen R, Mohkamsing S, De Vries B, et al. Rapid antibody test for fragile X syndrome. Lancet 1995;345:1147-8.

2 Willemsen R, Smits A, Mohkamsing S, et al. Rapid antibody test for diagnosing fragile $\mathrm{X}$ syndrome: a validation of the technique. Hum Genet (in press)

3 Pieretti M, Zhang FP, Fu YH, et al. Absence of expression of the FMR-1 gene in fragile X syndrome. Cell 1991;66:81722.

4 Hansen RS, Gartler SM, Scott CR, et al. Methylation analysis of CGG sites in the CpG island of the human FMR1 sis of CGG sites in the CpG island
gene. Hum Mol Genet 1992;1:571-8.

5 Hoogeveen AT, Oostra BA. The fragile X syndrome. $f$ Inherited Metabol Dis (in press).

6 Verheij C, Bakker CE, de Graaff E, et al. Characterization and localization of the FMR-1 gene product associated with fragile X, syndrome. Nature 1993;363:722-4.

7 Rousseau F, Heitz D, Biancalana V, et al. Direct diagnosis by DNA analysis of the fragile $\mathrm{X}$ syndrome of mental retardation. N Engl f Med 1991;325:1673-81.

8 Oostra BA, Jacky PB, Brown WT, Rousseau F. Guidelines for the diagnosis of fragile $\mathrm{X}$ syndrome. 7 Med Genet 1993; 30:410-13.

9 Verkerk AJ, de Vries BB, Niermeijer MF, et al. Intragenic probe used for diagnostics in fragile X families. $A m \mp M e d$ Genet 1992;43:192-6.

10 Willemsen R, Oosterwijk JC, Los FJ, et al. A new approach for prenatal diagnosis of fragile $X$ syndrome. Lancet 1996 348:967-8. 